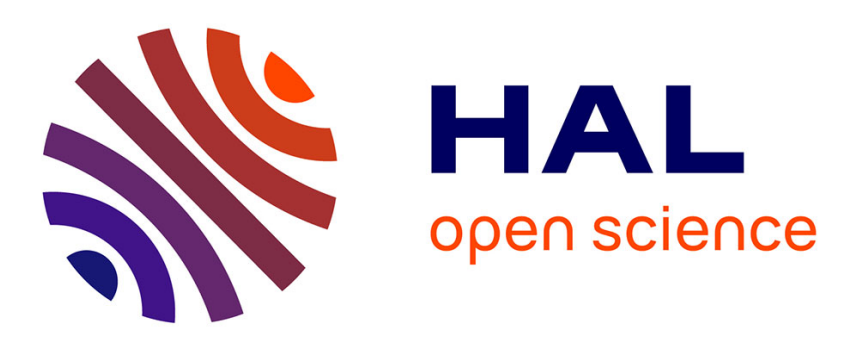

\title{
Noxious gas emissions above former coal and iron mines in Lorraine due to the presence of iron sulphides Candice Lagny
}

\section{To cite this version:}

Candice Lagny. Noxious gas emissions above former coal and iron mines in Lorraine due to the presence of iron sulphides. EnvironmentalEarth Sciences, 2015, 74 (7), pp.6303-6313. 10.1007/s12665-0154654-6 . ineris-01276262

HAL Id: ineris-01276262

https://hal-ineris.archives-ouvertes.fr/ineris-01276262

Submitted on 19 Feb 2016

HAL is a multi-disciplinary open access archive for the deposit and dissemination of scientific research documents, whether they are published or not. The documents may come from teaching and research institutions in France or abroad, or from public or private research centers.
L'archive ouverte pluridisciplinaire HAL, est destinée au dépôt et à la diffusion de documents scientifiques de niveau recherche, publiés ou non, émanant des établissements d'enseignement et de recherche français ou étrangers, des laboratoires publics ou privés. 


\title{
Noxious gas emissions above former coal and iron mines in Lorraine due to the presence of iron sulphides
}

Candice Lagny, INERIS (Institut National de l'Environnement industriel et des RISques), Parc technologique Alata 60550 Verneuil-en-Halatte, France, candice.lagny@ineris.fr, tel: $+33(0) 344556562$, fax number: +33(0)34455 6700

\begin{abstract}
Studies were carried out in the iron and coal basins of Lorraine (North-East of France) which indicated that oxygen-depleted air and carbon dioxide was being emitted into built-up areas related to former mine workings. Investigations were carried out to determine the origin of this gas production indicated that carbon dioxide production could be caused by the oxidation of iron sulphide minerals (pyrite and marcasite) and reaction of sulphuric acid with carbonates minerals to produce carbon dioxide gas. These reactions have produced highly mineralised mine water with circum-neutral $\mathrm{pH}$ values and a low content of dissolved metals and metalloids. Through a bibliographic study, similar neutral mine drainage has been observed and assumptions were made on the reactions which could take place. A conceptual model is proposed to explain the gas emissions.
\end{abstract}

Key words Noxious gas emission · Iron and coal old mines · Sulphides · Water · Oxygen · Carbonates

\section{Introduction}

The aim of this paper is to understand through the studies carried out by INERIS on two different old mine basins (an iron one and a coal one), what we observe as noxious gas emissions in built-up areas, how this gas production occurred, what is the explanation of this phenomena through several in situ investigations and which are the consequences on water characteristics like its $\mathrm{pH}$ and its mineralisation.

In a town (whose name will not be cited) located in the Lorraine coal basin (in the North-East of France), above a former coal mine, variations of atmospheric air composition are observed in the basements of some houses. They are characterised by a high concentration of $\mathrm{CO}_{2}$ gas (up to $8 \% \mathrm{vol}$.) in the atmosphere and a low concentration of $\mathrm{O}_{2}$ (down to 7\%vol.). These gas emissions occur generally during atmospheric pressure drops. They can affect people who are exposed; in the past, some people lost consciousness (Pokryszka, 1999). Some residential areas of the iron basin of Lorraine are affected by noxious gas emissions (under-oxygenated and carbon dioxide-loaded air mixtures) too.

The most spectacular phenomenon occurred in Moyeuvre-Grande town, especially in the district located very close to the former underground mine workings. Some inhabitants observed faulty working gas cookers and boilers located in cellars (Grabowski and Pokryszka, 2003). In France, legal requirements indicate that air should contain no more than $1 \%$ vol. for $\mathrm{CO}_{2}$ and at least $19 \%$ vol. for $\mathrm{O}_{2}$.

The average atmospheric volumetric content is $20.9 \%$ vol. for oxygen and $0.03 \%$ vol. for carbon dioxide.

The potential health effects of air with excess $\mathrm{CO}_{2}$ and depleted oxygen concentration decrease are numerous and their significance depends on the gas composition: specific symptoms (excitation and depression moments, central temperature and blood pressure decrease, and skin blood flow increase) are known to take place for $\mathrm{CO}_{2}$ concentrations around $3 \%$ and $\mathrm{O}_{2}$ concentration between 15 to 17\% (Bonnard et al., 2005). Death can occur for $\mathrm{CO}_{2}$ concentrations higher than $10 \%$ or with $\mathrm{O}_{2}$ concentration lower than $6 \%$ (Falcy et al., 2012). Apart from these clinical effects, $\mathrm{CO}_{2}$ polluted and under-oxygenated air is likely to increase $\mathrm{CO}$ production risks in affected houses. To understand the source of the problem, some accesses in these old mines (iron and coal mines of Lorraine) were equipped with specific gas monitoring devices and samples of mine water were collected for chemical analysis and air and water quality was measured. These accesses were located close to the phenomena observed. A bibliographic study was conducted to try to explain the processes and a conceptual model is also proposed to explain the observations that were made.

The work was undertaken within the framework of a program funded by the French Ministry in charge of Mines in collaboration with the Lorraine local administration, GEODERIS, and FEDER (Fonds Européen de Développement Régional) Lorraine. 


\section{Sites studied}

\section{The Lorraine iron basin}

The iron-bearing horizon occurs in two basins (Fig. 1): the Briey-Longwy basin in the north and the Nancy basin in the south. The Briey-Longwy basin is divided into three main parts (the northern, the central and the southern basins, separated by faults and with a hydrogeological independence). The land surface in this basin varies in altitude (in the northern part, from 355 to $440 \mathrm{~m}$ Above Sea Level for the shafts and from 210 to $335 \mathrm{~m}$ ASL for the adits). Air intakes and gas outflows were observed by cracks generated by exploitation and by accesses which are not closed.

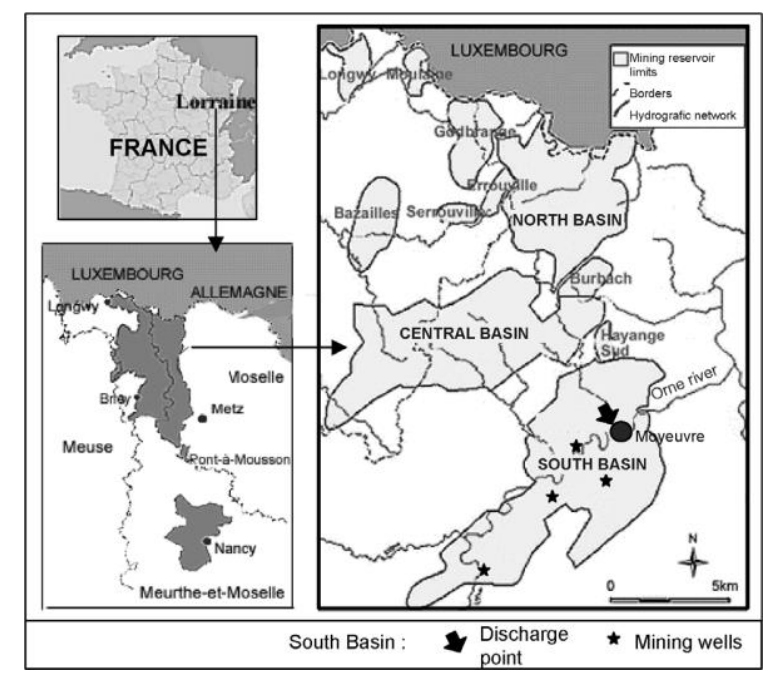

Fig. 1 Geographic location of the Lorraine iron basin (Collon et al., 2006)

In the northern part, mine dewatering ceased in 2005 and water has been discharging from mines since March 2008 at an elevation of $205 \mathrm{~m}$ NGF while in the southern part, the mines were closed in 1995 and water began to discharge in October 1998.

This iron deposit (10 - $65 \mathrm{~m}$ thick) dates from the Aalenian (Jurassic). It consists of a ferruginous limestone with marly intercalations. The ore is separated from the overlying marly intercalation by a layer of coarse grained shelly limestone (named "crassin"). The iron-bearing succession is overlain by the Bajocian Formation, a micaceous marl (5 - $25 \mathrm{~m}$ thick) which in turn is overlain by the Dogger limestone aquifer formation (40 - $80 \mathrm{~m}$ thick).

The Bajocian Formation has been fractured by mining, enabling water to infiltrate into mine galleries.

In the southern basin, five mineralised levels were mined. According to their composition and their chemical reactivity, three groups were differentiated (Collon et al., 2006): "shelly limestone" (or "crassin"), "marly hanging walls", and "marly intercalations". Hanging-wall rocks of the grey and yellow layers are included in the crassin group. It is made up of carbonates, quartz and goethite. The "marly hanging walls" are an intermediate group between the crassin and the marly intercalations.

The marly intercalations contain pyrite, sulphate minerals, phyllosilicates, plagioclase and microcline, and carbonates, quartz and goethite like the crassin.

\section{The Lorraine coal basin}

The geological and hydrogeological context can be summarised by (in order of decreasing age):

- The Carboniferous:

- the Westphalian deposit comprises numerous exploited coal seams of different thicknesses. These seams are located $600 \mathrm{~m}$ depth below the surface.

- $\quad$ the Stephanian stratigraphic units: they comprise conglomerates, shales and sandstones whose thickness reaches $200 \mathrm{~m}$;

- The Permian comprises dolomitic conglomerates and sandstones that are not very permeable and represents a stratigraphic level of 25 - $50 \mathrm{~m}$ thick;

- The Triassic: sandstones of Lower Triassic age are red or yellow, and very porous; sandstones are around 200 $\mathrm{m}$ thick and they contain an important aquifer used for human activities and as a source of drinking water.

Carboniferous and Triassic aquifers were initially separated by an aquitard composed of rocks of Permian age. Due to the mining workings, fractures were induced in Permian rocks. This has induced large cone of depression to 
develop in some part of the Triassic aquifer, and as a result hydraulically connected to Carboniferous aquifer. Intense dewatering was necessary to allow coal exploitation to take place.

As dewatering was stopped in 2006, potentiometric heads in the Carboniferous level have been rising and in July 2012, were around $+135 \mathrm{~m}$ ASL (i.e. $90 \mathrm{~m}$ deep).

Coal mining has caused discontinuous deformations subsidence between Carboniferous and Triassic stratigraphic levels in several areas, with a maximum collapse of $15 \mathrm{~m}$ (DREAL 2012). This has induced many cracks which can allow air and water intakes in the ground and gas outflows.

\section{Materials and methods}

\section{The Lorraine iron basin}

Monitoring systems were installed on several mine accesses more or less closed to the phenomena observed in order to understand gas flow mechanisms and to evaluate the composition of gases over time for various old mines.

\section{Several parameters were measured}

- External parameters such as barometric pressure and air temperature on the surface;

- Gas parameters such as gas velocity and flow direction, $\mathrm{O}_{2}$ and $\mathrm{CO}_{2}$ gas concentration, radon volumetric activity, gas temperature and differential pressure.

Some of the gas monitoring stations have been in operation for more than ten years such as the stations in G37 and $\mathrm{G} 7$ adits located in the low part of North iron basin at Moyeuvre-Grande town

Figure 2 shows a typical measurement station, put in G7 adit.

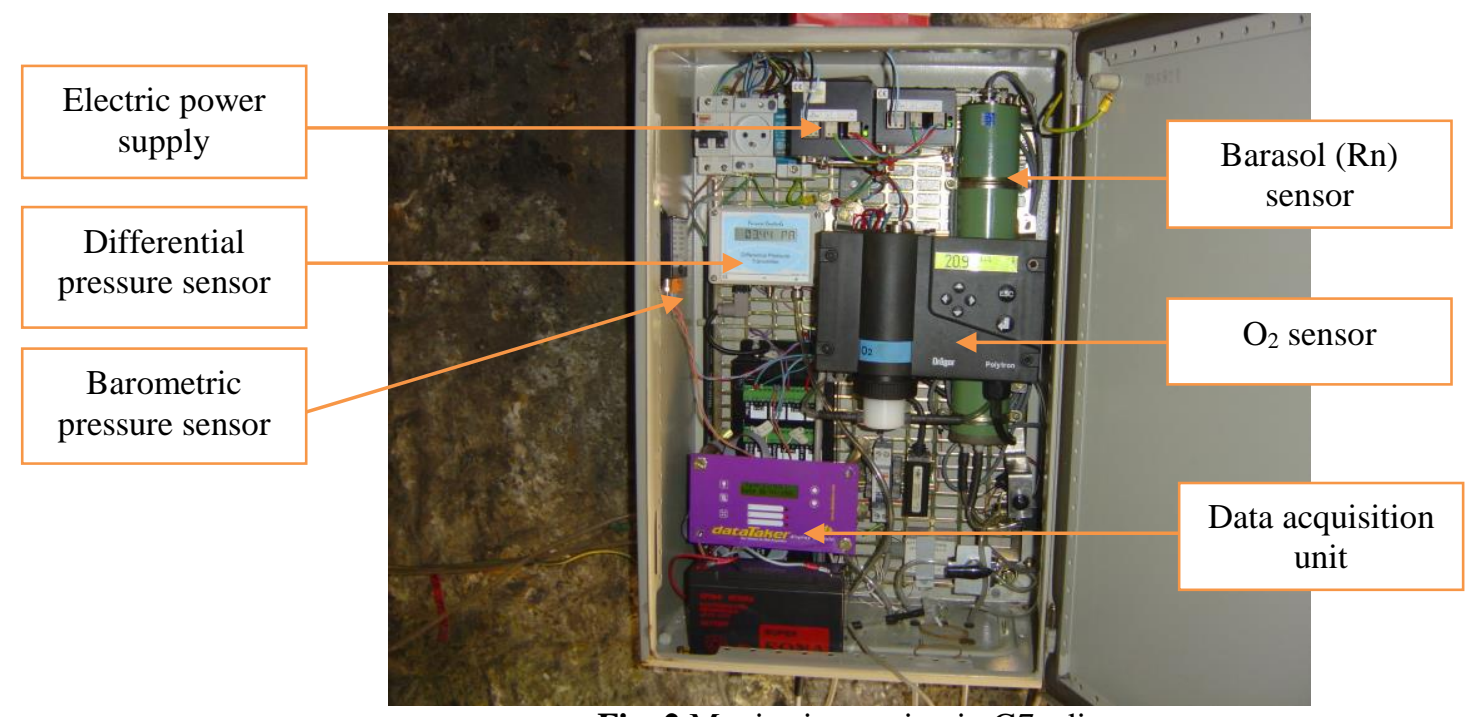

Fig. 2 Monitoring station in G7 adit

The low part of the North iron basin contains three galleries as shown on Fig. 3: Knutange, Charles and Charles Ferdinand galleries. 


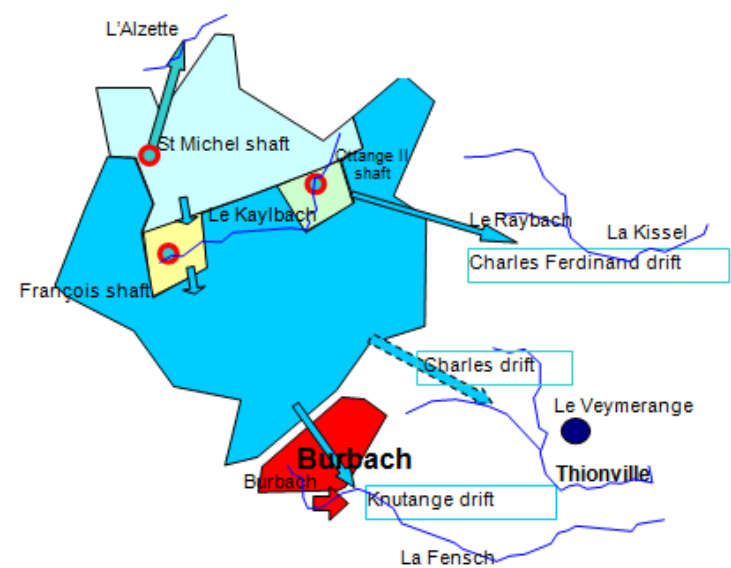

Fig. 3 Overflowings, shafts and water drainage areas in the North iron basin (Source: DRIRE Lorraine/GEODERIS, from Bentivegna and Lafortune, 2009)

The reservoirs' relations of the North basin are schematically explained on Fig. 4.

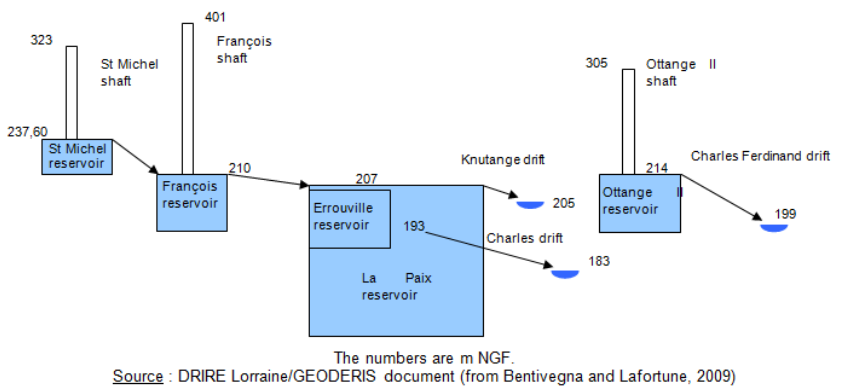

Fig. 4 Relations between underground hydrological mining reservoirs in the North iron basin (the surface altitude are designed in $\mathrm{m}$ NGF)

The overflowing of "La Paix reservoir" began in March 2008 at 207 m ASL by the Havange shaft which is located in Knutange gallery (Fig. 5). The river called "La Fensch" is the main river that received water overflows from the north iron basin. Investigations were undertaken at this location and downstream of the overflowing point to determine the mine water characteristics in June and in November 2008.

In situ measurements were made by INERIS in 2008 with a multi-parameters probe and water samples were taken in June 2008 and sent to the laboratory to be analysed.

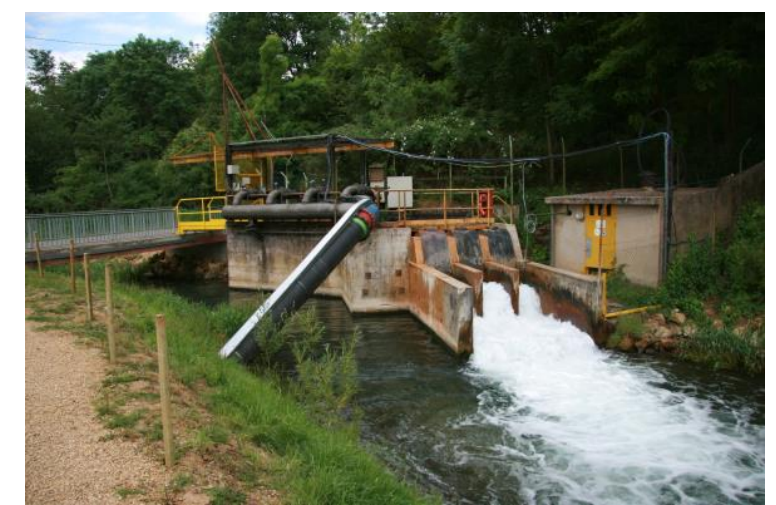

Fig. 5 Bassompierre or Knuttange water overflowing in the Fensch River

\section{The Lorraine coal basin}

A borehole was drilled during March 2012 down to the zone where the oxidation of iron sulphides was predicted to occur in order to confirm the concomitant presence of water and atmospheric oxygen necessary for the chemical reactions to proceed. The method of continuous core drilling was employed and the core equipment 
was outfitted with a tube that had fringes to permit the flowing of gas from the strata encountered. Gas composition measurements were conducted in the borehole. Some specific analyses were carried out on intact rock samples.

Water analyses were made in situ (temperature, $\mathrm{pH}$, and electric conductivity were measured with a multiparameters probe) and some samples were analysed in the laboratory for more accurate analysis (Degrelle, 2012). The water analysed was sampled in the borehole itself.

\section{Results and discussion}

\section{The Lorraine iron basin}

\section{Noxious gas production}

The gas composition, monitored continuously in the Moyeuvre-Grande reservoir, for example, at G37 and G7 adits has shown $\mathrm{O}_{2}$ consumption accompanied by a less than proportional production of $\mathrm{CO}_{2}$.

The results of previous studies carried out between 1999 and 2003 lead us to consider pyrite oxidation coupled with dissolution of calcite by the produced sulphuric acid as the most convincing hypothesis to explain the $\mathrm{CO}_{2}$ emission and $\mathrm{O}_{2}$ consumption (Pokryszka and Grabowski, 2003).

The reaction balance can be written as

$$
\mathrm{FeS}_{2}+3.75 \mathrm{O}_{2}+2 \mathrm{CaCO}_{3}+1.5 \mathrm{H}_{2} \mathrm{O} \leftrightarrow \mathrm{Fe}(0 \mathrm{H})_{3}+2 \mathrm{CO}_{2}+2 \mathrm{SO}_{4}^{2-}+2 \mathrm{Ca}^{2+}
$$

As a result, one mole fraction of pyrite needs - to be oxidised - the consumption of 15/4 mole fractions of oxygen and produces 2 mole fractions of carbon dioxide. So, the ratio between oxygen and carbon dioxide will be equal to 1.875 which is represented by the dark line (plotted on figure 7) whose equation is

$$
y=-1.875 x+20.9(2)
$$

This result is in accordance with a literature review on geochemical reactions observed in similar mining development cases.

Data registered on G37 adit were partly presented beneath. Oxygen content versus carbon dioxide is plotted on Fig. 6. Decreases in $\mathrm{O}_{2}$ gas content (which can reach less than 13 vol\%) were observed during summer periods with increases of $\mathrm{CO}_{2}$ content (which can reach more than $4 \mathrm{vol} \%$ ). On the contrary, during winter periods, atmospheric air enters in the adit. This result confirms that the natural thermal draught temperature is the main driving force for gas migration from the old mining works towards the surface (Pokryszka, 1999, Pokryszka and Grabowski, 2003, Lagny, 2011 and 2014).

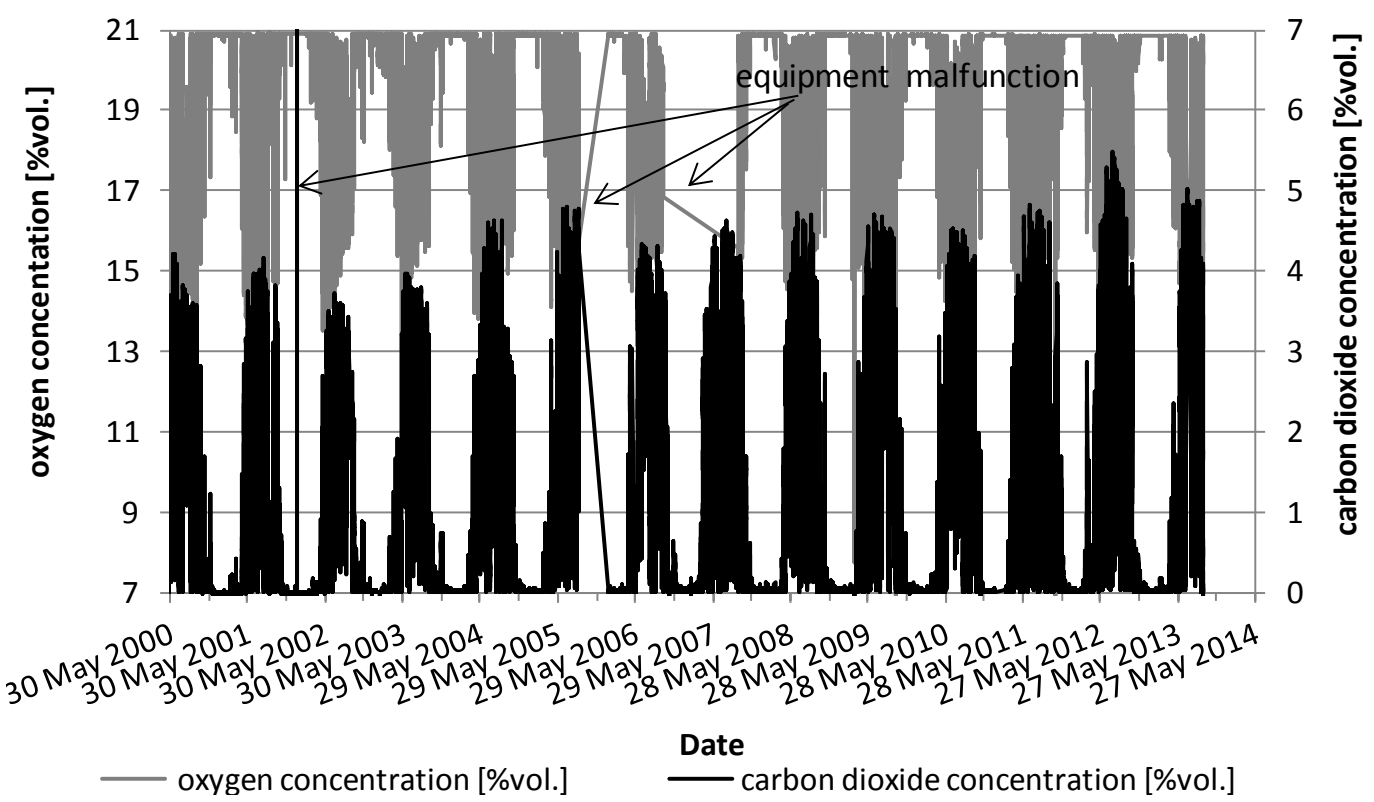

Fig. 6 Part of the data registered on G37 adit (Moyeuvre-Grande town) from April 2000 to April 2014 (Lorraine iron basin) 
To verify the evolution of the geochemical process of noxious gas production, part of the monitoring dataset was examined in more detail. During summer period (gas outflow), concentration of $\mathrm{CO}_{2}$ versus $\mathrm{O}_{2}$ concentration in gas was plotted to observe if the proportion between the two gases verifies the supposed geochemical reaction (Fig. 7).

The graphic shows that there is a great similarity with the theoretic line, though during the chosen period (between 07/06/13 and 08/07/13), short atmospheric air entries were observed.

This result supports the hypothesis that sulphide oxidation followed by carbonate dissolution is the source of the carbon dioxide and oxygen depletion observed in gas emissions from the mines. The reactions which have been observed in Moyeuvre-Grande since 1999 are still occurring.

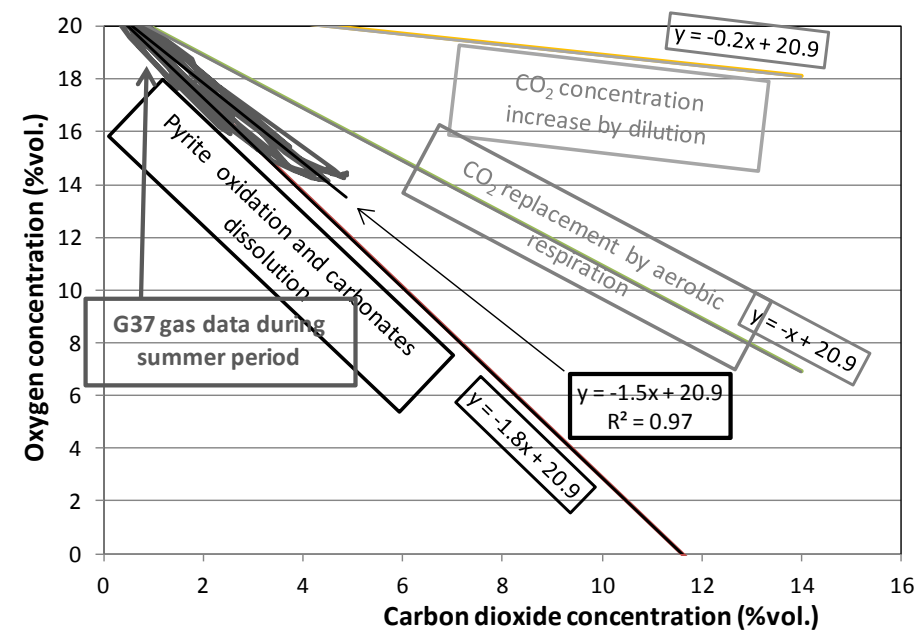

Fig.7 Oxygen concentration plotted versus carbon dioxide concentration for different reactions

The results of the gas monitoring led us to examine the effects of mine water discharges on the Fensch River.

\section{Water chemical analysis}

The mine water discharges in the central and south parts of the iron basin has affected water quality in the region (Préfecture de la région Lorraine, 2004). The most significant changes in water quality are increases concentrations of soluble salts (sulphates, sodium and magnesium) and the presence of other substances including elevated concentrations of iron, manganese, boron, hydrocarbons, phenols have also been observed.

The most significant change in water quality is the high concentration of sulphate due to the effects of pyrite oxidation. It is likely that similar water quality changes will also take place in mine water discharges in the northern part of the basin.

Water analysis which were collected at Knuttange water overflowing are listed in table 1 (Bentivegna and Lafortune, 2009).

Table 1 Data collected above and downstream of the water overflowing (Bentivegna and Lafortune, 2009)

\begin{tabular}{|c|c|c|c|c|c|c|}
\hline \multirow[t]{2}{*}{ Date } & \multicolumn{3}{|c|}{ upstream } & \multicolumn{3}{|c|}{ downstream } \\
\hline & Temperature $\left({ }^{\circ} \mathrm{C}\right)$ & $\mathrm{pH}$ & $\begin{array}{l}\text { Electric conductivity } \\
{[\mu \mathrm{S} / \mathrm{cm}] \text { at } 25^{\circ} \mathrm{C}}\end{array}$ & Temperature $\left({ }^{\circ} \mathrm{C}\right)$ & $\mathrm{pH}$ & $\begin{array}{l}\text { Electric conductivity } \\
{[\mu \mathrm{S} / \mathrm{cm}] \text { at } 25^{\circ} \mathrm{C}}\end{array}$ \\
\hline June 2008 & 16.1 & 7.8 & 637 & 13.6 & 7.5 & 2660 \\
\hline November 2008 & 10.2 & 7.7 & 595 & 12.9 & 7.2 & 2538 \\
\hline
\end{tabular}

The mine water discharges induce a decrease of the river's temperature in summer and an increase in winter. This result demonstrates the buffer effect of the underground mine water whose temperature is relatively stable, around $13^{\circ} \mathrm{C}$. The $\mathrm{pH}$ variation is not very important between upstream and downstream but a small $\mathrm{pH}$ decrease can be observed downstream of the discharge point. However there was a significant increase in the electrical conductivity of the river water downstream of the discharge point (Table 1). The water of the river is around four times more 
mineralized downstream of the discharge point. These values are depending on the water flow value which was $0.86 \mathrm{~m}^{3} / \mathrm{s}$, the $16^{\text {th }}$ of June 2008. In March 2008, the flow of water reached $2.87 \mathrm{~m}^{3} / \mathrm{s}$. It is even so representative of a mine water mineralisation which was confirmed by laboratory analyses.

Water samples from the river were collected in June 2008 and analysed at the laboratory (table 2).

Table 2 Water analyses on samples collected upstream and downstream the overflowing point (Bentivegna and Lafortune, 2009)

\begin{tabular}{lll}
\hline Parameter & Upstream the overflowing point (mg/l) & Downstream the overflowing point (mg/l) \\
\hline bicarbonates & 321 & 550 \\
chlorides & 22 & 26 \\
nitrates & 7 & 3 \\
sulphates & 111 & 1550 \\
calcium & 111 & 301 \\
magnesium & 14 & 217 \\
potassium & 2 & 7 \\
sodium & 15 & 176 \\
Total Dissolved Solids & 603 & 2831 \\
\hline
\end{tabular}

Great differences in the chemical composition of river water were observed upstream and downstream of the discharge point, especially for sulphates, calcium, magnesium and sodium where concentration increases of up to 400 per cent were observed. Through the parameters measured in this study, the Fensh river quality is falling at the discharge point of "Lapaix reservoir". Downstream, the punctual measurements clearly show the influence of the mine water from the old workings with a great variation of mineralisation and especially a great increase in sulphates, calcium, magnesium and sodium ions. Similar observations have been made in the past in other part of the iron Loraine basin by Collon (2004), specifically, in the southern and central parts of the basin, where the $\mathrm{pH}$ can range from 6.8 to 7.8, and relatively high concentrations of sulphate, sodium, magnesium, manganese and boron were measured in discharges from mine dewatering. The concentrations of some chemical constituents in the discharge water tend to decrease with time in particular, sulphate, sodium, magnesium, calcium, bicarbonate, chloride and potassium.

Metals (trace metals) and metalloids in solution were not found in significant concentration neither in the coal.

\section{The Lorraine coal basin}

\section{Noxious gas production}

The presence of high content of $\mathrm{CO}_{2}$ and the lack of $\mathrm{O}_{2}$ were confirmed by gas measurements conducted by INERIS in the borehole, at different times during and after the drilling. This was achieved with a portable gas analyser, a pump and a flexible associated to a measuring tape to know the depth. The measures were done as quickly as possible and the pump was stopped between each measure in order to perturb the less as possible the gas distribution in the borehole.

One of the numerous gas compositions ( $\mathrm{CO}_{2}$ and $\mathrm{O}_{2}$ gas contents) with depth is presented below (Fig. 8). 


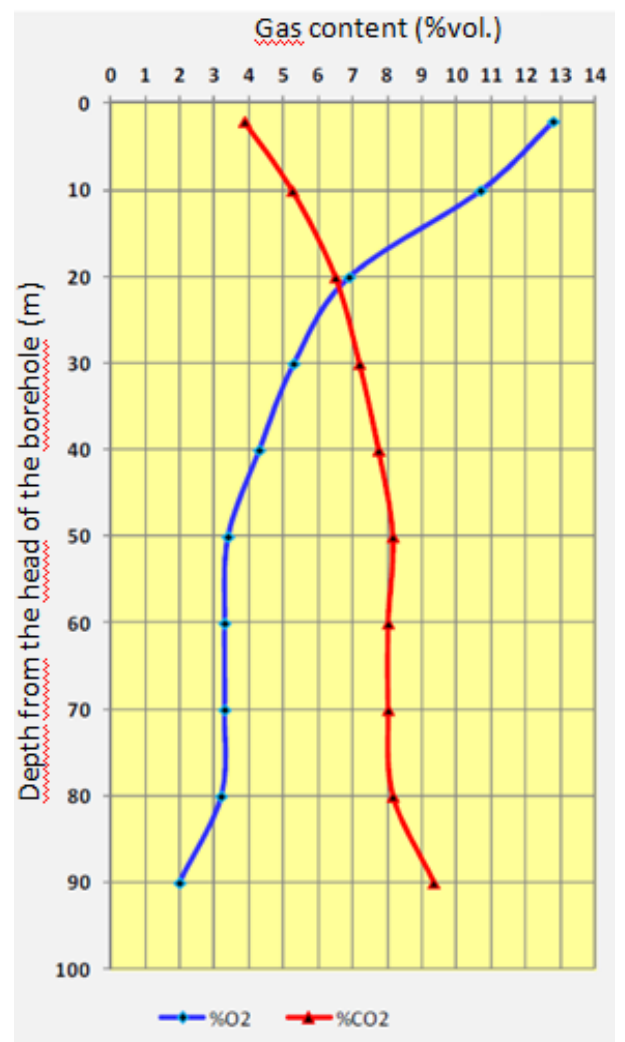

Fig 8. Distribution of $\mathrm{CO}_{2}$ and $\mathrm{O}_{2}$ gas content with depth, two months after the drilling (Degrelle, 2012)

The gas distribution evolves regularly during the fifty first meters. Also, the $\mathrm{CO}_{2}$ gas content is increasing from $3.9 \%$ ( $2 \mathrm{~m}$ depth) to $8.2 \%$ (50 $\mathrm{m}$ depth) while the $\mathrm{O}_{2}$ gas content is decreasing from 12.8 to $3.4 \mathrm{vol} \%$.

Then, the gas contents are relatively stable until $80 \mathrm{~m}$ depth after what $\mathrm{CO}_{2}$ gas content is rising to $9.3 \mathrm{vol} \%$. and $\mathrm{O}_{2}$ gas content is decreasing to $2 \mathrm{vol} \%$.

After these measures have been realised several times in various meteorological conditions, experiments were conducted to explain this gas production which is characterised by a high $\mathrm{CO}_{2}$ gas content and a low $\mathrm{O}_{2}$ gas content.

Investigations were carried out on rock samples from the borehole with a SEM (Scanning Electron Microscope) in order to determine their mineralogy.

Core samples (one core was around $2 \mathrm{~m}$ length) were selected in order to have all types of facies encountered on the drilling and a homogeneous spatial repartition of the samples.

The analyses showed that ferrous sulphurs (pyrite or marcasite) were identified in twelve samples (among 21), associated or not with carbonates, and located between 50 and $100 \mathrm{~m}$ depth.

Figure 9 shows one example of a negative obtained where marcasite can be observed. 


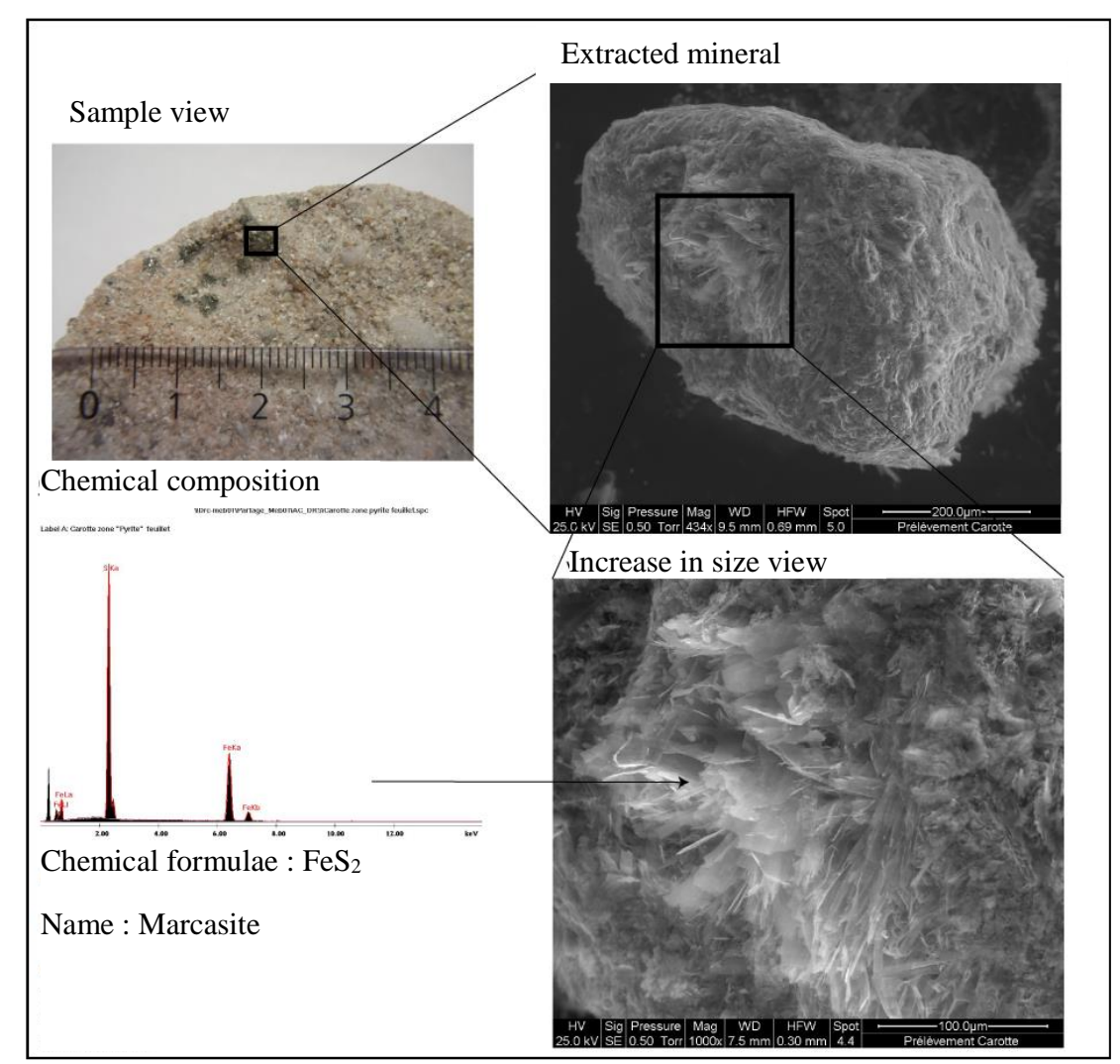

Fig. 9 Example of a negative obtained with the SEM (Lagny et al., 2013)

Marcasite (or white iron pyrite) was found on several samples both in a pristine and a partially oxidised state. It is a ferrous sulphide mineral which is more easily oxidised than pyrite.

Rock samples were put in batches with demineralised water in order to examine, if possible whether sulphide oxidation and carbonate reactions would continue.

It is also possible to test the interaction between water and sandstones collected at Cocheren in the borehole and to observe if noxious gas can be produced as it can be observed in the borehole. The experimental protocol consists on $\mathrm{CO}_{2}$ and $\mathrm{O}_{2}$ concentrations measurements of a rock sample put in a batch with water. The rock sample was chosen depending on gas analysis results in the borehole and core samples characterisations.

The samples selected are located where noxious gaseous compositions were measured in the borehole or where ferrous sulphurs were observed. In order to increase the speed of the reaction, the samples were crushed. Half of the batch (see Fig. 10) was filled in with rock samples and water was added so as to create a saturated and an unsaturated part. Rock samples and each element of the batches were sterilised to eradicate bacteria which were not those implied in the reaction.

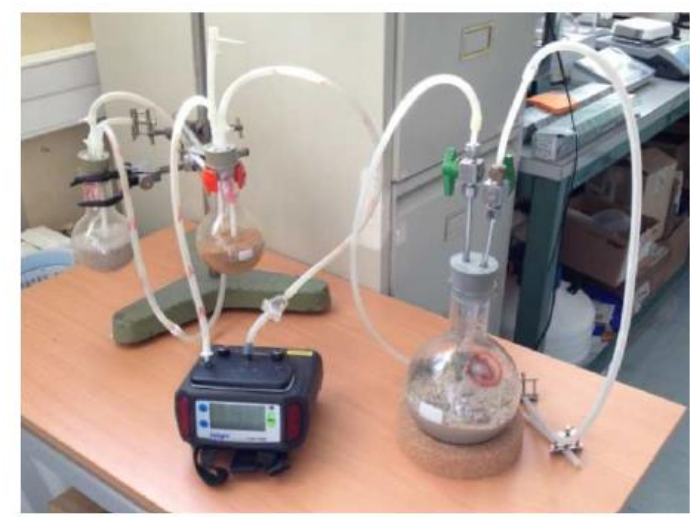

Fig. 10 Experiments conducted in batches (Degrelle, 2012)

The same analyser which was used in situ was taken to observe gas variations. The gas sampled for analysis was reinserted in the batch.

It was observed for batches containing rock samples with marcasite that $\mathrm{O}_{2}$ was consumed and $\mathrm{CO}_{2}$ was produced in the proportion of the supposed theoretic reaction, as the line plots on Figure 7. 
The oxidation of iron sulphide minerals (pyrite or marcasite) usually takes place in a number of steps [Agrinier (2010)].

In a first step, soluble ferrous ions are produced:

$$
4 \mathrm{FeS}_{2}+14 \mathrm{O}_{2} \text { (gas) }+4 \mathrm{H}_{2} \mathrm{O} \rightarrow 4 \mathrm{Fe}^{2+} \text { (aqueous phase) }+8 \mathrm{SO}_{4}^{2-} \text { (aq.) }+8 \mathrm{H}^{+}
$$

Then, ferrous ions are oxidised to form ferric ions via the following reaction:

$$
4 \mathrm{Fe}^{2+} \text { (aq.) }+\mathrm{O}_{2} \text { (g.) }+4 \mathrm{H}^{+} \text {(aq.) } \rightarrow 4 \mathrm{Fe}^{3+} \text { (aq.) }+2 \mathrm{H}_{2} \mathrm{O}
$$

And then, iron hydroxides precipitate:

$$
4 \mathrm{Fe}^{3+} \text { (aq.) }+12 \mathrm{H}_{2} \mathrm{O} \rightarrow 4 \mathrm{Fe}(\mathrm{OH})_{3}+12 \mathrm{H}^{+} \text {(aq.) (5) }
$$

Hence, $\mathrm{O}_{2}$ is consumed and the water is acidified by the cumulated production of $16 \mathrm{H}^{+}$. If carbonates are present, these can interact and generate $\mathrm{CO}_{2}$ production, according to:

$$
16 \mathrm{H}^{+} \text {(aq.) }+8 \mathrm{CaCO}_{3} \rightarrow 8 \mathrm{CO}_{2} \text { (g.) }+8 \mathrm{Ca}^{2+}+8 \mathrm{H}_{2} \mathrm{O}
$$

In fact, calcite is acidified, according to:

$$
\mathrm{CaCO}_{3}+2 \mathrm{H}^{+} \leftrightarrow \mathrm{Ca}^{2+}+\mathrm{H}_{2} \mathrm{CO}_{3} \text { (aq.) (7) }
$$

In case of gaseous phase presence, $\mathrm{H}_{2} \mathrm{CO}_{3}$ (aq.) is decomposing as:

$$
\mathrm{H}_{2} \mathrm{CO}_{3} \text { (aq.) } \leftrightarrow \mathrm{CO}_{2} \text { (g.) }+\mathrm{H}_{2} \mathrm{O}(8)
$$

The results of the study on gas production led us to examine water.

\section{Water chemical analysis}

During and after the drilling, physical and chemical parameters of water were measured as its temperature, its $\mathrm{pH}$ and its electric conductivity.

The Triassic sandstone groundwater has a conductivity ranged between 2.3 and $3.1 \mathrm{mS} / \mathrm{cm}$ and a temperature comprised between 14 and $18.5^{\circ} \mathrm{C}$ at $100 \mathrm{~m}$ depth (Lafortune, 2011), few kilometres far from the borehole.

The water level in the borehole was around $90 \mathrm{~m}$ depth. Water samples were collected and analysed in situ with a multiparameter probe. Some laboratory analyses were also conducted.

Data after the drilling are shown on Tables 3 and 4. The first analysis corresponds to an equilibrium period of the borehole with its environment.

Table 3 In situ water measurement in the borehole (Degrelle, 2012)

\begin{tabular}{llll}
\hline Date & Parameters & & \\
\cline { 2 - 4 } & Temperature $\left({ }^{\circ} \mathrm{C}\right)$ & $\mathrm{pH}$ & $\begin{array}{l}\text { Electric } \\
{[\mu \mathrm{S} / \mathrm{cm}]}\end{array}$ \\
\\
14 and 15 of May 2012 & 13.5 & 8.0 & 3360 \\
14 to 16 of November & 13.5 & 7.6 & 3151 \\
2012 & & & \\
\hline
\end{tabular}

The $\mathrm{pH}$ value is representative of near neutral $\mathrm{pH}$. Water temperature is the temperature of the ground at such depth and electric conductivity is indicative of an increase in the Total Dissolved Solids content which was around $300 \mu \mathrm{s} / \mathrm{cm}$ during the drilling.

Some samples were taken in May 2012 and sent to the laboratory to be analysed. The results are shown in Table 4. 
Table 4 Laboratory results on water samples taken in May 2012 at the borehole (Degrelle, 2012)

\begin{tabular}{|c|c|c|c|c|c|c|c|c|c|c|c|c|}
\hline $\begin{array}{l}F^{-} \\
(\mathrm{mg} / \mathrm{l})\end{array}$ & $\begin{array}{l}\mathrm{Cl}^{-} \\
(\mathrm{mg} / \mathrm{l})\end{array}$ & $\begin{array}{c}\mathrm{NO}_{2}^{-} \\
(\mathrm{mg} / \mathrm{l})\end{array}$ & $\begin{array}{l}\mathrm{Br}^{-} \\
(\mathrm{mg} / \mathrm{l})\end{array}$ & $\begin{array}{c}\mathrm{NO}_{2}^{-} \\
(\mathrm{mg} / \mathrm{l})\end{array}$ & $\begin{array}{l}P_{4}^{3-} \\
(\mathrm{mg} / \mathrm{l})\end{array}$ & $\begin{array}{l}\mathrm{SO}_{4}^{2-} \\
(\mathrm{mg} / \mathrm{l})\end{array}$ & $\begin{array}{l}\mathrm{Ca}^{2+} \\
(\mathrm{mg} / \mathrm{l})\end{array}$ & $\begin{array}{l}\mathrm{Mg}{ }^{2+} \\
(\mathrm{mg} / \mathrm{l})\end{array}$ & $\begin{array}{l}\mathrm{Na}^{+} \\
(\mathrm{mg} / \mathrm{l})\end{array}$ & $\begin{array}{l}K^{+} \\
(\mathrm{mg} / \mathrm{l})\end{array}$ & $\begin{array}{l}\mathrm{Si} \\
(\mathrm{mg} / \mathrm{l})\end{array}$ & $\begin{array}{l}\mathrm{HCO}_{3}^{-} \\
(\mathrm{mg} / \mathrm{l})\end{array}$ \\
\hline 0.0 & 89.9 & 0 & 0 & 0 & 0 & 819.9 & 22 & 6.4 & 815 & 10.6 & 4.3 & 976.7 \\
\hline
\end{tabular}

Concentrations in sulphate, sodium and carbonate ions are around $800 \mathrm{mg} / \mathrm{l}$, which is relatively high compared to the drinking water guidelines.

The values of conductivity measured during the drilling were around $300 \mu \mathrm{S} / \mathrm{cm}$ whereas those measured at the bottom of the borehole after a given time can be multiplied by ten. The $\mathrm{pH}$ is circum-neutral and high concentrations of sulphate, sodium and carbonate ions are observed.

These observations are typical of a neutral mine drainage.

\section{Discussion}

In the coal and iron Lorraine basins studied, the same type of gaseous phenomenon is observed. The presence of iron sulphide, with oxygen and water, induces its oxidation and carbonates presence brings on $\mathrm{CO}_{2}$ gas production. Related to water characteristics, the $\mathrm{pH}$ is near-neutral, high mineralisation is observed with great sulphate, sodium and carbonate ion concentrations.

Heavy metals (trace metals) in solution were not found in significant concentration neither in the coal Lorraine basin (though metals like iron and manganese were present), nor in the iron Lorraine basin.

In order to enhance knowledge on this phenomenon and to know if reactions of the same type are possible elsewhere, we have done a bibliographic study on pyrite oxidation processes which is exposed below and we have proposed a conceptual model to describe the likely processes.

\section{Bibliographic study and modelling proposal}

Active draining waters and in particular in closed mines are usually acidic and neutral drainage is just a result of acid mine drainage (AMD), when buffer phenomenon occurs.

Acid waters (Jonhson and Hallberg, 2005) typically pose a risk to the environment by their usually high concentration of metals (iron, aluminium, manganese and possibly other heavy metals) and metalloids (of which arsenic is generally of greatest concern).

In brief, the main cause of acidic metal rich mine drainage waters (Johnson, 2003) is the accelerated oxidation of iron pyrite $\left(\mathrm{FeS}_{2}\right)$ and/or other sulphides minerals, mainly due to air entry caused by dewatering.

The exposure of these minerals to both oxygen and water, as a consequence of the mining and processing of metal ores and coals, induces sulphides minerals oxidation.

These phenomena tend to be usually associated with the oxidation of pyrite, which is the most abundant sulphide mineral on the planet. Likewise, coal deposits contain variable amounts of "pyritic sulphur" (a generic term that includes other iron sulphide minerals such as marcasite) as well as organic sulphur.

At $\mathrm{pH}$ value above 4 , this may be mediated chemically or biologically, while below $\mathrm{pH} 4$, abiotic iron oxidation is negligible.

When mines are closed or abandoned and pumps turned off, the rising of the water table can lead to soluble sulphates leaching inducing contaminated groundwater being discharged, sometimes in a catastrophe vent which is not the case in the two cases studied here.

Another important problem is the potential of long-term pollution problem, as production of AMD may continue for many years after mines are closed (see BRGM, Agence de l'eau Rhin-Meuse, Direction régionale de l'environnement Lorraine, 2008 for the evolution of Lorraine iron basin).

Some AMD streams remain neutral to alkaline, although others show a marked decline in $\mathrm{pH}$ as they oxygenate. This is chiefly in the form of bicarbonate $\left(\mathrm{HCO}_{3}^{-}\right)$deriving from the dissolution of basic minerals (calcium carbonate) though as noted below, biological processes may also generate alkalinity in AMD streams.

This is the case (Mayo et al., 2000) in Wasatch Plateau located in Utah (USA) where there is an old coal mine. The coal was mined at a depth of about $350 \mathrm{~m}$ below the surface. Collapses occurred within hours or days, after coal was mined, forming roof-rock rubble composed of coal, sandstone, and mudstone. Until June 1993, all exposed minefloor, wall and roof areas were dusted with gypsum rock dust to retard fire and prevent explosion. In July 1993, dolomite was substituted for gypsum and pure limestone was substituted for the dolomite in October 1993.

Pyrite oxidation does not always result in acid drainage because of the buffering effect of abundant carbonate minerals. Indeed, the dissolution of gypsum (both native and gypsum dust used as rock dust) is also a significant 
contributor of $\mathrm{SO}_{4}{ }^{2-}$. Ion exchange of $\mathrm{Ca}^{2+}$ on the sodium zeolite analcime, which occurs in the coal, accounts for an increase in $\mathrm{Na}^{+}$concentrations. Oxidation of fugitive longwall emulsion fluids may also produce abundant gaseous $\mathrm{CO}_{2}$ some of which indirectly affect the total dissolved solid (TDS) content of mine drainage. It is postulated that the bacterial oxidation of the organic portion of the fugitive longwall mining machine emulsion fluid may liberate this gas which in turn may form carbonic acid and may result in the dissolution of carbonate minerals.

What we observed in Lorraine coal basin is quite similar in terms of observed substances concentrations. $\mathrm{SO}_{4}{ }^{2-}$ ions are linked to the presence of major cations (calcium, magnesium and sodium). Sodium may be liberating by argillaceous minerals that keep calcium in exchange which is not the case in the iron Lorrain basin. Moreover, are likely to be insufficient aluminosilicate minerals available in the system to neutralise acidic water.

So, for near-neutral $\mathrm{pH}$, the processes that are taking place can be quite various. Moses and Herman (1990) interested themselves to pyrite oxidation at circum-neutral $\mathrm{pH}$ where proton and metal concentration are low which is the case in our two case studies. They retained the reaction mechanism proposed by Goldhaber (1983) which considers that the initiation pyrite oxidation is due to the direct attachment of a dissolved oxygen (DO) molecule to the partially protonated pyrite surface. It has commonly been assumed that at near-neutral $\mathrm{pH}$, DO must be the direct oxidant due to the low solubility of Fe(III). Smith et al. (1968) and Moses et al. (1987) showed that Fe(III) is a very effective pyrite oxidant at this $\mathrm{pH}$ value.

Pyrite oxidation is typically far from equilibrium, whether represented by reaction (9) or reaction (10), which is the sum of reaction (9) and $14 \mathrm{X}$ reaction (11):

$$
\begin{gathered}
\mathrm{FeS}_{2}+14 \mathrm{Fe}^{3+}+8 \mathrm{H}_{2} \mathrm{O} \rightarrow 15 \mathrm{Fe}^{2+}+2 \mathrm{SO}_{4}^{2-}+16 \mathrm{H}^{+}(9) \\
\mathrm{FeS}_{2}+7 / 2 \mathrm{O}_{2(\mathrm{aq})}+\mathrm{H}_{2} \mathrm{O} \rightarrow \mathrm{Fe}^{2+}+2 \mathrm{SO}_{4}^{2-}+2 \mathrm{H}^{+}(10) \\
\mathrm{Fe}^{2+}+1 /{ }_{4} \mathrm{O}_{2(\mathrm{aq})}+\mathrm{H}^{+} \rightarrow \mathrm{Fe}^{3+}+1 / 2 \mathrm{H}_{2} \mathrm{O}(11)
\end{gathered}
$$

Moses et al. (1987) proposed an extension of the Singer-Stumm model of pyrite oxidation to circum neutral $\mathrm{pH}$ where the solubility of Fe(III) is so low that the reservoir of Fe (III) (aq.) is rapidly depleted by reduction on pyrite and $\mathrm{Fe}$ (II) oxidation becomes rate limiting because it is needed to maintain $\mathrm{Fe}(\mathrm{III})$ (aq.) concentrations.

They assumed that the reaction is zero-order in $\left[\mathrm{SO}_{4}{ }^{2-}\right]$ and $[\mathrm{Fe}(\mathrm{II})(a q)$.$] which are reaction products. They begin$ their low rate formulation (a macroscopic one) with the assumption that dependence on the ratio of total surface area to reaction solution volume $(\mathrm{A} / \mathrm{V})$ is first-order. With this consideration, the rate expression is writing with pyrite concentration measured in units consistent with the measurement of $\mathrm{SO}_{4}{ }^{2-}$ concentrations:

$$
\text { rate }=\frac{-\mathrm{d}[\text { pyrite }]}{\mathrm{dt}}=\frac{(0.5) \mathrm{d}\left[\mathrm{SO}_{4}^{2-}\right]}{\mathrm{dt}}
$$

The (0.5) factor reflects the stoeichiometric relationship between moles of pyrite oxidized and moles of $\mathrm{SO}_{4}{ }^{2-}$ produced (reactions 9 and 10).

The rate law is the product of the rate coefficient $k$ and the concentration of each species that participates in the reaction rose to a power that reflects the reaction order (reaction 13):

$$
\text { rate }=\mathrm{k}\left(\frac{\mathrm{A}}{\mathrm{V}}\right)^{1}\left[\mathrm{Fe}(\mathrm{II})_{(\text {aq. })}\right]^{0}\left[\mathrm{SO}_{4}^{2-}\right]^{0}\left[\mathrm{H}^{+}\right]^{0}\left[\mathrm{Fe}(\mathrm{III})_{(\text {aq. })}\right]^{0}[\mathrm{DO}]^{0}
$$

or

$$
\text { rate }=\mathrm{k}\left(\frac{\mathrm{A}}{\mathrm{V}}\right)(13)
$$

The rate coefficient was determined by experimental data, but some others assumptions have been made by the authors by considering (Lasaga, 1981) that the reaction order of equation (11) could be $n$ and so could be written like rate $=\mathrm{k}\left(\frac{A}{V}\right)^{n}$

They found with their laboratory experiments results that the reaction at near-neutral pH was first-order with respect to $\mathrm{A} / \mathrm{V}$.

According to the results, the Singer-Stumm model could be extended for pyrite oxidation.

But they also added that there is a need to develop relationships between understanding of these processes in simple systems like in their experiments, and in natural systems. Natural systems are more complicated, for example, due to the solution and solid phase compositions, the activity of biota (mainly bacteria) that could alter the rate or 
mechanisms of the reactions. Moreover, the proposed pyrite oxidation mechanism of this study is, in fact, compatible with their understanding of the means by which Thiobacillus bacteria accelerate pyrite oxidation.

As measured water $\mathrm{pH}$ in the Lorraine and coal basin studied parts is near-neutral, as Fe(III) appears not to be the major component of the reaction but oxygen seems to be essential in the reaction and as pyrite presence has been verified, the Singer-Stumm model might be proper for understanding and modelling in situ observed phenomena.

\section{Conclusion}

The presence of a high content of $\mathrm{CO}_{2}$ and the lack of $\mathrm{O}_{2}$ in gas emissions from mine accesses were confirmed by measurements in the borehole located in the Lorraine coal basin. Drilling and mineralogical investigations confirmed that marcasite, water, and carbonates are present on the site in the ground at different depths.

The hypothesis of marcasite or pyrite oxidation is proposed to explain noxious gas production.

Historical observations suggest that the same processes are taking place in the Lorraine iron basin. Past experiences and actual data support the hypothesis that the observed gas emissions are associated with the oxidation of iron sulphide minerals coupled with the dissolution of carbonates.

The oxidation of iron sulphides in the presence of carbonate minerals could account for the observed emissions of carbon dioxide and oxygen-depleted air, and can produce drainage with a circum-neutral $\mathrm{pH}$ value, that has high dissolved salt content, and contains low concentrations of metals other than iron and manganese.

Such drainage is usually called neutral mine drainage.

In the future, some new water samples should be taken to measure $\mathrm{Fe}$ (II) and Fe(III) concentrations in order to confirm that the Singer-Stumm model is appropriate to the case of these parts of iron or coal Lorraine basins studied.

Acknowledgments This work was supported by the ministry in charge of mining industry, GEODERIS, GISOS (Groupement de recherche sur l'Impact et la Sécurité des Ouvrages Souterrains) - Research Group for the impact and safety of underground cavities, and FEDER (Fonds Européen de Développement Régional) Lorraine.

\section{References}

Agrinier P., (2010) Rapport d'expertise sur l'origine des émanations de $\mathrm{CO}_{2}$ à XXXX

Bentivegna G. et Lafortune S. (2009) Suivi des effets de l'ennoyage du basin ferrifère nord lorrain: Résultats pour l'année 2008. Programme EAT-DRS03. Rapport INERIS référencé DRS-09-95102 du 03/04/2009

Bonnard N., Brondeau M.T., Falcy M., Jargot D., Miraval S., Protois J.C., Schneider O. (2005) Dioxyde de carbone. Fiche toxicologique INRS FT 238, Numéro CAS : 124-38-9, édition 2005

BRGM, Agence de l'eau Rhin-Meuse, Direction régionale de l'Environnement LORRAINE (2008) Bassin ferrifère. Surveillance eau. Les chroniques d'information. Juin 2008

Collon P., Fabriol R., Bues M. (2006) Modelling the evolution of water quality in abandoned mines of the Lorraine Iron Basin. Journal of Hydrology (2006), 328: 620-634

Collon P. (2004) Evolution de la qualité de l'eau dans les mines abandonnées du bassin ferrifère lorrain. De l'expérimentation en laboratoire à la modélisation in situ. Mémoire de thèse présentée à l'Institut National Polytechnique de Lorraine le 21 octobre 2003

Degrelle F. (2012) Etude des mécanismes de production et de migration de gaz dans le sous-sol de la ville de XXXX Rapport INERIS référencé DRS-12-129607-13345A du 14/12/12.

DREAL (2012) Ennoyage des mines du bassin houiller lorrain: http://www.lorraine.developpementdurable.gouv.fr/suivi-de-1\%E2\%80\%99ennoyage-du--bassin-a3212.html

Goldhaber M. B. (1983) Experimental study of metastable sulfur oxyanion formation during pyrite oxidation at ph 6-9 and $30^{\circ} \mathrm{C}$. American Journal Sciences, 238: 193-217

Grabowski D., Pokryszka Z. (2003) Emissions gazeuses à partir des vides miniers dans le bassin ferrifère lorrain Colloque International Après-mine, 5-7 février 2003, Nancy

Falcy M., Marc F., Petit J.M., Sallé B. (2012) Travaux dans une atmosphère appauvrie en oxygène. Préconisations pour la protection des travailleurs et prévention. ED 6126. Aide mémoire technique INRS, février 2012

Johnson D. B., Hallberg K. B. (2005) Acid mine drainage remediations options: a review. Science of Total Environment, 338: 3-14

Johnson D. B. (2003) Chemical and microbiological characteristics of mineral spoils and drainage waters at abandoned coal and metal mines. Water Air Soil Pollution: Focus,2003 3: 47-66 
Lafortune S. (2011) Emissions gazeuses dans le quartier de la cité XXXX à XXXX. Diagnostique du phénomène et préconisations. Rapport INERIS référencé DRS-10-114230-12929A

Lagny C. (2011) Moteurs d'écoulement et émissions de gaz de mine dans le bassin houiller lorrain et dans le bassin ferrifère lorrain en cours d'ennoyage et après ennoyage. Rapport INERIS DRS-11-111952-00760A du 30/01/2011

Lagny C., Lafortune S., Charmoille A., Pokryszka Z., Degrelle F. and Kimmel M. (2013) $\mathrm{CO}_{2}$ gas production understanding above a partly flooded coal post-mining area. $14^{\text {th }}$ Int. Symposium on Water-Rock Interaction, WRI 14. Procedia Earth and Planetary Science, 7:455-458

Lagny C. (2014) The emissions of gases from abandoned mines: role of atmospheric pressure changes and air temperature on the surface. Environ Earth Sci 71:923-929 doi 10.1007/s12665-013-2495-8,

Lasaga A.C. (1981) Rate laws of chemical reactions. In Kinetics of Geochemical Processes (eds. A.C. Lasaga and R.J. Kirk-Patrick), Review in Mineralogy, 8:1-68

Mayo A.L., Peterson E.C., Knavits C. (2000) Chemical evolution of coal mine drainage in a non-acid producing environment, Wasatch Plateau, Utah, USA. Journal of Hydrology, 236: 1-16

Moses C.O., Herman J.S. (1990) Pyrite oxidation at circumneutral pH. Geochimica et Cosmochimica Acta, 55: 471-482

Moses C.O., Nordstrom D.K., Herman J.S. and Mills A.L. (1987) Pyrite oxidation by dissolved oxygen and by ferric iron. Geochimica et Cosmochimica Acta, 51: 1561-1571

Pokryszka Z. (1999) Essai d'évaluation du rôle potentiel du tirage naturel dans le phénomène des émissions gazeuses à Moyeuvre-Grande. Rapport INERIS référencé DRS-99-23255/R01 du 27 décembre 1999

Pokryszka Z., Grabowski D. (2003) On the surface noxious gas emissions from old iron mines. $30^{\text {th }}$ International Conference of Safety in Mines Research Institutes, South African Institute of Mining and Metallurgy, 2003

Préfecture de la région Lorraine (2004) Ennoyage du bassin ferrifère nord : analyse du devenir de l'eau dans le bassin versant de la Fensch, décembre 2004

Smith E.E., Svanks K. and Shumatek (1968) Sulfide to sulfate reaction studies. Proc. Symp. Coal Mine Drainage Res, $2^{\text {nd }}$, Mellon, Institute, Pittsburgh, p1-11 